\title{
외이도 골종
}

\author{
춘해병원 이비인후과 \\ 이종담 · 박호선 · 곽동훈 · 윤상호
}

\section{A Osteoma of the External Auditory Canal}

Jong Dam Lee, MD, Ho Sun Park, MD, Dong Hun Kwak, MD and Sang Ho Youn, MD

Department of Otolaryngology, Choon Hae Hospital, Busan, Korea

\begin{abstract}
-ABSTRACT -
Osteoma of the external auditory canal is an uncommon slow growing benign tumor which may arise from the outer half of the bony canal. It is a characteristically unilateral, pedunculated hard mass. In the temporal bone, osteoma commonly arise in the external auditory canal. Osteoma is usually asymptomatic until their large size results in conductive hearing loss or ear fullness. CT scan is helpful to delineate the size, location and relationship of adjacent structure. The best way to treat is surgical removal under good exposure. In this case, we have experienced a osteoma of external auditory canal in 33-years-old male. We report this case with literature review. (J Clinical Otolaryngol 2002;13:213-215)
\end{abstract}

KEY WORDS : Osteoma $\cdot$ External auditory canal.

\section{서 론}

외이도 골종은 서서히 자라는 양성 골성 종양으로서 막 성골의 내부 혹은 말단에서 발생한다. 자라면서 주위 조 직에 압력을 가해 2차적인 증상을 나타내기도 한다. 주로 부비동, 하악골에 발생하며 드물게 측두골에 발생한다. 그 중 외이도에서 제일 많이 발생하고 ${ }^{1)}$ 유양돌기, 인부 등에서도 발생할 수 있다. ${ }^{23)}$ 저자들은 외이도에서 발생 한 골종을 치험하였기에 보고하는 바이다.

\section{증 례}

33세 남자로 우연히 발견된 좌측 외이도의 종물을 주

논문접수일 : 2002년 9월 17일

심사완료일 : 2002년 10월 5일

교신저자 : 이종담, 부산광역시 부산진구 범천동

춘해병원 이비인후과

전화 : (051) 645- 8971. 전송 : (051) 645- 8980

E- mail : JDLee1@kornet.net
소로 내원 하였으며, 내원 당시 청력저하, 이루, 이내 충 만감, 이통, 어지러움증 등의 다른 증상은 호소하지 않 았다. 과거력상 외상은 없었으며 가족력상 특이소견은 없었다.

이학적 검사상 외이도에 경계가 명확한 견고한 구형 의 종물이 $1.0 \times 0.8 \times 0.8 \mathrm{~cm}$ 의 크기로 관찰되었고 후 하방으로 $1 \mathrm{~mm}$ 정도의 반월형 간격이 있었다 Fig. 1).

측두골 전산화 단층촬영상 좌측 외이도 협부의 외측 전벽에서 기시한 경계가 명확한 단발성의 종물이 유경 (pedunculated)으로 나타나고, 고농도 음영(high density) 을 보여 골종을 의심케 하였고(Fig. 2), 다른 이상 소견은 관찰되지 않았다.

국소마취 하에 전이개 절개(endaural incision) 로 접 근하여 골종의 부착부를 확인한 후 골종을 덮고 있는 피 부를 박리하여 보존하면서, 절골기를 이용하여 제거하였 으며 피부이식이 필요할 정도의 결손은 발생하지 않았다. 환자는 수술 후 4일째 별다른 합병증을 보이지 않고 퇴 원하였다. 


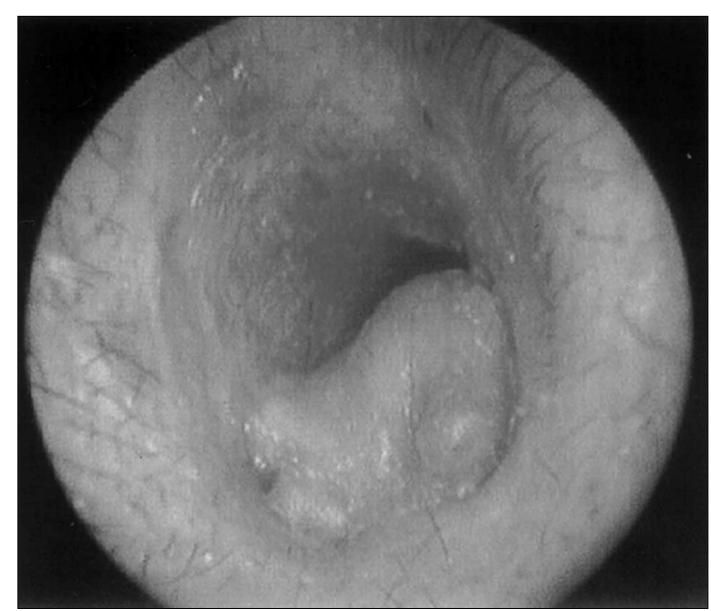

Fig. 1. Otoscopic finding of left ear show a $1.0 \times 0.8 \times 0.8$ $\mathrm{cm}$ sized mass which attached on anterior bony canal.

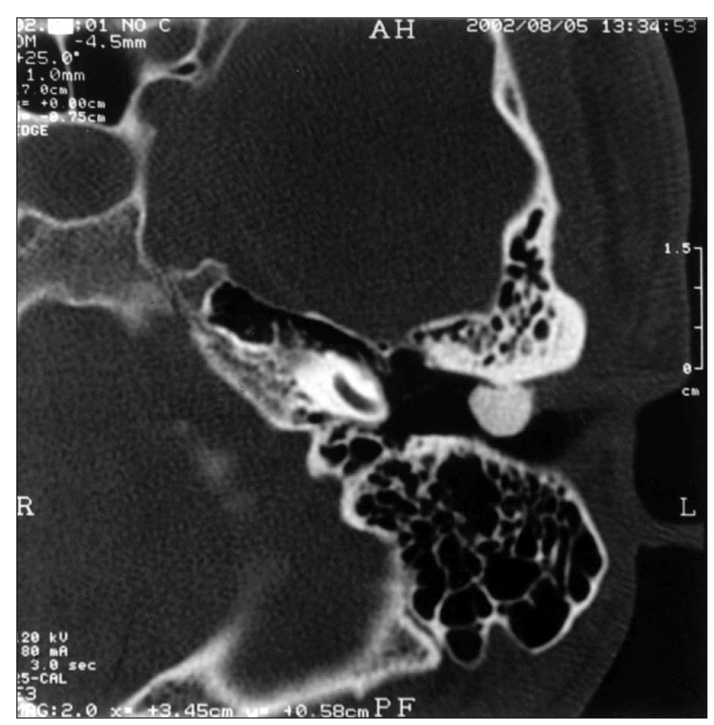

Fig. 2. Temporal bone CT scan demonstrates a round pedunculated, radiodense mass.

병리조직학적 소견은 성숙한 층판골로 구성된 소주들 (trabeculae) 과 사이에 산재된 섬유조직과 혈관들을 관 찰할 수 있었다 Fig. 3).

\section{고 찰}

골종은 치밀골(compact bone) 또는 해면골(cancelous bone) 의 양성 종양으로서 막성골( membraneous bone)

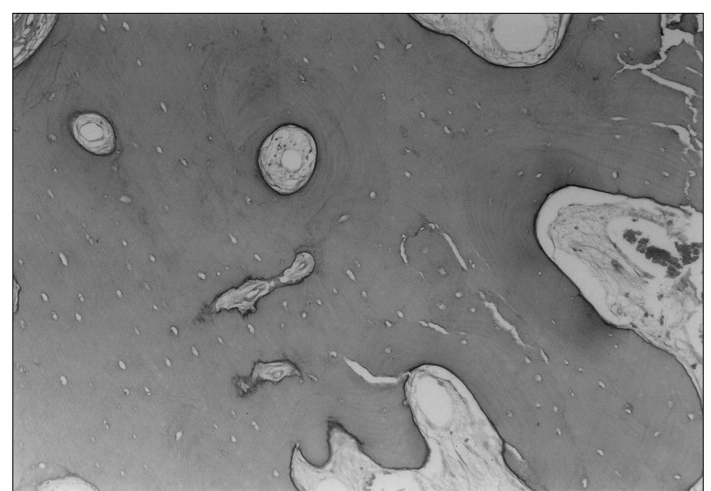

Fig. 3. Microphotograph of osteoma is showing trabeculae of lamellar bone and loose fibrous tissue with blood vessels $(H-E, \times 40)$.

내 또는 그 주변부에서 발생하며 시일이 경과함에 따라 서서히 자라는 양성종양이다. ${ }^{1)}$ 주로 부비동과 하악골에 서 많이 발생하며, 측두골에서는 외이도에 가장 많이 발 생하고 ${ }^{4)}$ 유양돌기가 두 번째 호발 부위이다. ${ }^{5)}$ 그 외에 인 부, 내이도, 악관절와, 이관, 추체능, 추체첨, 경상돌기, 갑 각융기, 침골, 중이의 추체융기 등 측두골의 어느 부위에 서나 발생 가능하다고 보고되어 있다.

측두골 골종의 병인으로 외상, 감염, 선 요소(glandular factor), 유전, 뇌하수체 기능부전이 제시되었지만 아직 그 원인은 명확하지 않다. ${ }^{3) 6)}$

외이도 골종은 어느 연령층에서나 발생할 수 있으며 남 자에서 더 호발한다고 알려져 있다. ${ }^{1) 3)}$ 서서히 자라는 종 양의 특성으로 인해 초기에는 아무런 증상없이 그냥 지 내다가 외이도가 이전(cerumen)과 파기물에 의해 폐 색됨으로서 처음 발견된다. ${ }^{13) 4)}$ 나타날 수 있는 흔한 증 상으로서는 이내 충만감, 전음성 난청등이 있으나 본 예 에서는 관찰되지 않았다. 그 외에 인접 구조물과의 관계 에 의해 이통, 측두부 동통이 ${ }^{7)}$ 생길 수 있으며 어지러움, 소양감 등도 있을 수 있다. 약 $30 \%$ 에서 외이도 골종은 만성 외이도염을 유발한다고 알려져 있다. ${ }^{8)}$

외이도 골종은 단발성, 유각성 종괴로 외이도 협부의 외측에서 발생하며 단단한 골성 경도를 가지는 다양한 크 기의 형태로 나타난다. ${ }^{1{ }^{4)}}$ 골종이 고실인상봉합선 또는 고실유양돌기봉합선에 부착한다고 알려져 있으나 ${ }^{4)}$ 본 예 에서는 외이도의 전벽으로 봉합선과의 연결은 없었다.

진단은 이학적 검사와 방사선학적 검사로 가능하며 특 
히 전산화 단층촬영이 종괴의 크기와 인접 구조물과의 관 계를 잘 보여주기 때문에 유용하다.

병리조직학적으로 골막과 외이도의 편평상피로 덮혀져 있으며, 내부에 층판골(lamellar bone)에 의해 섬유혈관 성 통로들이 둘러 싸여 있는 양상을 보인다. ${ }^{4) 6)}$

감별하여야 할 질환으로 외골증( exostosis) 이 있다. 외 골증은 냉수에 의한 반복적인 자극에 의해 생기는 외이도 에서 가장 흔한 골성 병변으로 양측성으로 생기며 외이도 협부 내측에 광범위한 골의 융기를 보이는 질환이다. ${ }^{14)}$ 병리조직학적으로 골종과 달리 섬유 혈관성 통로는 존재 하지 않는다. ${ }^{9}$ 수술적 제거가 어렵기 때문에 외이도 골종 과 반드시 감별하여야 한다. ${ }^{4)}$

종양의 치료원칙은 외과적 절제이다. 크기가 작은 경우 에는 보존적인 치료를 할 수 있으나 증상을 유발할 시에 는 수술적으로 제거하여야 한다. ${ }^{3) 4)}$ 크기가 작고 외이도 협부의 외측에 위치한 경우에는 경외도(transcanal) 접근 법으로 제거가 가능하고, 협부의 내측에 위치하는 경우 에는 후이개(retroauricular) 접근법으로 제거가 가능하다. 본 예에서는 골종이 협부의 외측, 외이도의 전벽에 위치하 여 전이개(endaural) 접근법으로 종괴를 제거하였다. ${ }^{1)}$

재발율은 완벽한 절제 후에는 드물며, 주위조직과의 관 계가 복잡할 때는 술전 종양의 범위를 정확히 파악한 후 종양을 충분히 노출시켜 제거를 하여야 한다.

\section{결 론}

저자들은 33세 남자에서 발생한 좌측 외이도에 생긴 골종을 치험하였기에 문헌고찰과 함께 보고하는 바이다.

중심 단어 : 골종 외이도.

\section{REFERENCES}

1) Sheehy JL. Diffuse exostoses and osteoma of the external auditory canal: A report of 100 operations. Otolaryngol Head Neck Surg 1982;90:337-42.

2) Kemink JL, Graham MD. Osteomas and exostoses of the external auditory canalmedical and surgical management. J Otolaryngol 1982;11:101-6.

3) Nam BH, Chang JW, Byun SN, Park CI. Osteoma of the external auditory canal. Korean J otolaryngol 2000;43:373-6.

4) Graham MD. Osteoma and exostoses of the external auditory canal. Ann Otol 1979;88:566-72.

5) Choi WC, Kim SK, Park MK, Lee SY. A case of mastoid osteoma. Korean J otolaryngol 2002;44:617-9.

6) Denia A, Perez F, Canalis RR, Graham MD. Extracanalicular osteoma of temporal bone. Arch Otolaryngol 1979;105: 706-9.

7) Shenoy P, Paulose KO, Khalifa SA, Sharma R. Osteoma of the ear canal presenting with headache. J Laryngol Otol 1989;103:683-4.

8) Fleming JP. Osteoma of the mastoid. Can J Surg 1966;9: 402-5.

9) Fenton JE, Turner J, Fagan PA. A histopathologic review of temporal bone exostoses and osteomata. Laryngoscope 1996; 106:624-8. 